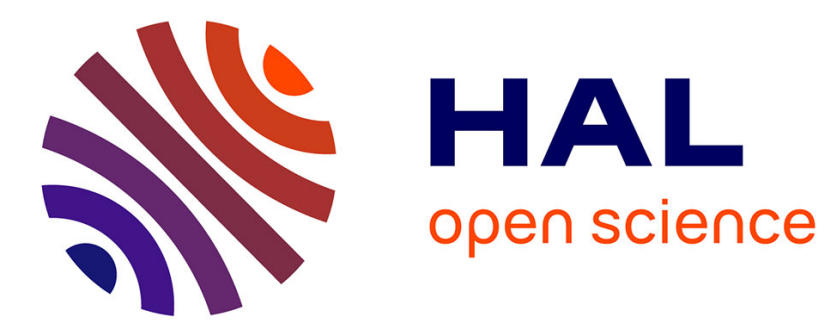

\title{
Open Innovation and Co-creation in the Public Sector: Understanding the Role of Intermediaries
}

Mila Gasco-Hernandez, Rodrigo Sandoval-Almazan, J. Ramon Gil-Garcia

\section{To cite this version:}

Mila Gasco-Hernandez, Rodrigo Sandoval-Almazan, J. Ramon Gil-Garcia. Open Innovation and Cocreation in the Public Sector: Understanding the Role of Intermediaries. 9th International Conference on Electronic Participation (ePart), Sep 2017, St. Petersburg, Russia. pp.140-148, 10.1007/978-3319-64322-9_12. hal-01703331

\section{HAL Id: hal-01703331 \\ https://hal.inria.fr/hal-01703331}

Submitted on 7 Feb 2018

HAL is a multi-disciplinary open access archive for the deposit and dissemination of scientific research documents, whether they are published or not. The documents may come from teaching and research institutions in France or abroad, or from public or private research centers.
L'archive ouverte pluridisciplinaire HAL, est destinée au dépôt et à la diffusion de documents scientifiques de niveau recherche, publiés ou non, émanant des établissements d'enseignement et de recherche français ou étrangers, des laboratoires publics ou privés. 


\title{
Open Innovation and Co-Creation in the Public Sector: Understanding the Role of Intermediaries
}

\author{
Mila Gasco-Hernandez ${ }^{1 \text { [0000-0002-6308-8519] }}$, Rodrigo Sandoval-Almazan 20000-0002-7864-6464] \\ and J. Ramon Gil-Garcia ${ }^{3[0000-0002-1033-4974]}$ \\ ${ }^{1-3}$ Center for Technology in Government, University at Albany, USA \\ ${ }^{2}$ Universidad Autonoma del Estado de Mexico, Mexico \\ mgasco@ctg.albany.edu, rsandovala@uaemex.mx, jgil- \\ garcialctg.albany.edu
}

\begin{abstract}
Innovation is a recurring theme in public administration. Governments around the world are always exploring innovation alternatives. However, the way public organizations innovate has evolved in the last few years from "in-house" innovation to open innovation. Although the literature is rich in references to innovation in the private sector, how open innovation processes can become a true and effective tool for governments is still an underexplored topic. The few studies that have tackled it have mainly addressed one main question: how can a successful private sector practice be introduced in public sector organizations? In contrast, this paper aims at making a contribution to the existing literature on open innovation in the public sector by addressing one issue that is key in open innovation processes: the role of intermediaries. Intermediaries are important actors in the open innovation ecosystem as they facilitate activities in all stages of the innovation process and help government agencies to achieve their goals.
\end{abstract}

Keywords: Open innovation, co-creation, intermediaries, i-labs, living labs.

\section{Introduction}

Innovation is a recurring theme in public administration. It has been used to frame the transformation of public sector organizations in order to enhance the effectiveness, efficiency, and legitimacy of their public value creation processes [9]. As needs of citizens are changing, and technology is advancing, there is an immense need for innovation in the public sector. On one hand, citizens have higher expectations about public services and government interventions. On the other, public managers and elected politicians have growing ambitions concerning improved public governance mechanisms and tighter control. Finally, public tasks have become more and more complex and have developed into "tangled problems" or even "wicked problems" - problems that are often too difficult to be solved by a single entity and include many different layers of complexity [40].

Although innovation is not a new concept in the public sector [17] [7], the way public administrations have innovated throughout time has evolved, coinciding with different waves of administrative reforms [37]. According to [32], public sector innovations can 
be the result of internal innovation processes (which are policy-induced and use employees' suggestions), externalized innovation processes (which depend on contractors and adapt to industry standards), and open innovation processes (which are based on crowdsourcing and involve external professional and amateur problem solvers).

Although the literature is rich in references to innovation in the private sector, how open innovation processes can become a true and effective tool for governments is still an underexplored topic [33] [6] [20]. Only recently such approach has been seen in research into public sector innovation [18].

Most of the studies that have addressed open innovation in the public sector have focused on drivers of adoption, success factors, and innovation outcomes (among other, [33], [34], [6], [35], [19], [29], [22], [20], [10], [23]). However, there is not enough research that specifically refers to public sector open innovation intermediaries and explores their role in innovation processes in the public sector [6].

Based on a review of recent literature, this paper proposes a government open innovation framework, which explicitly acknowledge the role of intermediaries. It analyzes theories and concepts of open innovation in the public sector and contributes to the public sector innovation literature by analyzing the role of intermediaries in open innovation processes that take place in the public sector.

The paper is organized in four sections, including the foregoing introduction. Section two presents the concept of open innovation and analyzes how it has been implemented in the public sector. The type and role of intermediaries in (public) open innovation processes is explained in section three. Finally, section four provides some conclusions and suggests ideas for further research on open innovation processes in the public sector.

\section{Open innovation}

Open innovation is a term that was coined in the private sector. [12] defines open innovation as "the use of purposive inflows and outflows of knowledge to accelerate internal innovation, and expand the markets for external use of innovation, respectively" (p. 1). He actually sets open innovation in opposition to closed innovation [12] [13]. Regarding the latter, he states that "successful innovation requires control. In other words, companies must generate their own ideas that they would then develop, manufacture, market, distribute and service themselves (...). This approach calls for self-reliance: If you want something done right, you've got to do it yourself" ([13]: 36). At the same time, the author defines open innovation as a strategy by which firms commercialize external (as well as internal) ideas by deploying outside (as well as in-house) pathways to the market: "specifically, companies can commercialize internal ideas through channels outside of their current businesses in order to generate value for the organization (...) In addition, ideas can also originate outside the firm's own labs and be brought inside for commercialization. In other words, the boundary a firm and its surrounding environment is more porous, enabling innovation to move easily between the two" ([13]: 37). 
[14] confirm the growth of academic research in the domain of open innovation. The authors present the fields in which open innovation has attracted most attention: management, business, industrial engineering, operations research and management science, and planning and development. However, out of 1,965 articles, [14] only find 14 related to public administration, what leads the authors to insist on the opportunities of open innovation in the public sector as well as on the need to formulate public policies that support open innovation in a given society.

[34] shows that implementing open innovation methodologies in the public sector can indeed have myriad positive benefits, including improved awareness of social problems, more effective practices based on broad citizen experience, and increased trust between government and citizens. However, open innovation approaches in the private sector are context dependent: they cannot readily be transferred to the public sector [34] [31]. Consequently, the implementation of open innovation in the public sector needs to take the unique characteristics of the sector into consideration

In the public sector, open innovation has inspired the concept of collaborative innovation: collaborative processes and interactions between internal and external stakeholders can spur innovation in the public sector and help find innovative solutions to complex problems. Therefore, collaborative innovation could have similar benefits as open innovation. However, although it is thought as happening across organizational boundaries, it is also inside government.

From a more practical point of view, most research on open innovation in the public sector has focused on open government and open data initiatives (among other, [28], [33], [14], [45], [11], [35], [27]). In these studies, open innovation has been conceptualized as a paradigm to move from closed organizations to open, transparent, and collaborative ones. Authors have therefore seen the potential of open data/open government projects, often based on prizes and contests that use online open innovation platforms, to boost open innovation in the public sector.

However, to realize the practical benefits of this transformative practice and to develop theory, still, more research needs to focus on understanding how innovation occurs through open data activities [45] but, also, on exploring additional topics that can make a contribution to the literature on open innovation in the public sector. It is necessary to go beyond open government and open data and focus on open innovation as the main topic and consider all the different examples or types of open innovation in the public sector. It also seems important to understand the role of different actors in the open innovation ecosystem.

\section{Open innovation intermediaries in the public sector}

In their review, [14] list some of the main themes that have emerged in the literature on open innovation. The innovation process is by far the most researched topic, followed by strategy, product development, and toolkit/users: "based on our analysis, we find that a large amount of research investigates the outside-in (inbound) side of open inno- 
vation. This research deals with how firms can leverage external knowledge and technology to accelerate internal innovation" (p. 8). Interestingly enough, the authors find several references to collaboration with intermediaries.

Innovation intermediaries can be defined as external organizations and individuals that support companies in their innovative activities by gathering, developing, controlling and disseminating external knowledge by providing various resources and regulating the innovation networks [6] [25].

[12] mentions that intermediaries can operate in different ways: some function as agents (representing one side of a transaction) and others as brokers (representing both sides of a transaction). More precise is [24] who considers the following roles of intermediaries in the private sector: 1) to help to facilitate internal and external technology commercialization, 2) to connect innovation seekers to innovation providers, 3) to help companies to screen external markets, 4) to understand the technology market better, 5 ) to make searching tasks easier for companies, 6) to reduce search cost of the companies, and 7) to in-license, co-develop and acquire external intellectual properties or technologies. Along the same lines, [30] indicates that innovation intermediaries have, indeed, a variety of profiles and functions that might be grouped under three general headings: connection, collaboration and support, and provision of technological services.

However, [24] also argues that the role of intermediaries is not just to link different parties, a commonly held belief, but also to search and transform ideas and provide personalized solutions that fit to individual clients. He also adds that intermediaries such as Yet2.com, Ninesigma, Innocentive, and IdeaConnection have changed the innovation spectrum dramatically giving rise to new industries.

The literature reveals a wide variety of innovation intermediaries [25] that range from public and private incubators to technological top institutes and, more recently, to living labs ([6], [1], [2]). Most of these intermediaries have collaborated with private rather than public organizations [6].

Although in the context of private open innovation management, the role of intermediaries has been investigated thoroughly (among other, [21], [3], [44], [25]), there is not enough research that specifically refers to public sector open innovation intermediaries and explores their role in innovation processes in the public sector [6].

According to [6], public open innovation intermediaries can be understood as "public or private organizations that intermediate between city halls and other organizations" (p. 312). Building on this meaning and on the works of [5] and [42], in this paper, we contribute a more elaborated definition that understands open innovation intermediaries as public and private organizations that intermediate between local/regional/national governments and other organizations and individuals with the purpose of enhancing public sector innovation capacity by means of applying open innovation methodologies: knowledge exchange, co-creation techniques and participatory methods.

Thus, intermediaries are important in at least two ways. First, they help to enhance government capabilities for open innovation. Second, they link governments with their context, including people and organizations that can contribute to their innovation efforts. Additionally, the concept also helps to focus the study of open government innovation on the actors involved and the role each of them plays in the innovation process. 
In sum, understanding the role of intermediaries contributes to the theory and practice of open innovation in the public sector.

The literature reveals two main types of public open innovation intermediary organizations: innovation labs and living labs.

Innovation labs, or i-labs, are seen as experimental forms of government acting as innovation catalysts [15]. [41] refer to them as experimental organizations, that is, spaces within the public sector to experiment and take risks. They are usually peripheral, agile, and smaller and operate under different rules than typical civil service organizations. Mindlab in Denmark and Nesta in the UK are examples of i-labs: "these are small organizations with low funding levels and diverse sources of funding, and they are typically engaged in short term projects and relatively removed from political leadership" [26].

There is very little research on public sector innovation labs beyond descriptive, and at times normative, overviews. In an attempt to bridge this gap, [41] analyzed 35 such organizations all over the world and concluded that:

- "I-labs were created to enable cross-disciplinary and citizen-driven approaches, while at the same time they produce most of their work for or with the ministerial departments and other government agencies" (p. 13).

- "I-labs are rather unique organizations and diverse in their mission, expected to act as change agents within public sector and enjoy large autonomy in setting their targets and working methods" (p. 21).

- "I-labs are typically structurally separated from the rest of the public sector and expected to be able to attract external funding as well as "sell" their ideas and solutions within the public sector" (p. 21).

- "I-labs tend to be small structures, specializing on quick experimentations and usually lack the capabilities and authority to significantly influence upscaling of new solutions or processes" (p. 21).

- "The main capabilities of i-labs are their ability to jump-start or show case user-driven service re-design projects" (p. 21).

- ICT play a central role in i-labs. "Many of the tasks i-labs carry out are directly or indirectly related to developing ICT-based solutions for the citizens as well as public sector" (p. 22).

Living labs are settings or environments for open innovation, which offer a collaborative platform for research, development, and experimentation with product and service innovations in real-life contexts, based on specific methodologies and tools, and implemented through specific innovation projects and community-building activities [38]. In living labs, different stakeholders (firms, public organizations, individual citizens, and researchers, among other) interact and collaborate in innovation processes.

Living labs are therefore conceived as a strategic opportunity to improve the creation of multi-stakeholder partnerships with citizens at the center. As a result, they have often been defined as public, private and people partnerships (PPPP) for user-driven open innovation [36]. Along the same lines, [16] state that living labs are increasingly wellestablished innovation intermediaries that support the implementation of the quadruple helix model, an innovation approach based on cooperation between firms, universities, public organizations and users [4]. 
[39] identifies two types of living labs: those focused on supporting companies and creating an ecosystem of innovation that benefits both private companies and public organizations and those focused on opening innovation processes to citizens (the socalled citizen labs).

Citizen labs, such as the Mexican PIDES Innovación Social and Laboratorio para la Ciudad (LabCdMX), have become particularly popular in Latin America as spaces for citizen innovation that pay special attention to the democratization of innovation [43]. Their exponential growth has come hand in hand with the idea that public innovation has to be social innovation [8], and therefore has to 1) produce long lasting outcomes that are relevant, given the needs and challenges of different groups in society, 2) aim at changing the social relationships and the governance among the involved stakeholders, 3) involve relevant stakeholders in the design, implementation or adoption of an innovation, which corresponds to the notion of open innovation, and 4) see the process of innovation as a learning and reflection process.

Table 1 summarizes the main differences and similarities between i-labs and living labs.

Table 1. Differences and similarities between i-labs and living labs as open innovation intermediaries.

\begin{tabular}{|c|c|c|}
\hline & Innovation labs & Living labs \\
\hline Operation & Operate autonomously but inside government & $\begin{array}{l}\text { Operate autonomously } \\
\text { outside government }\end{array}$ \\
\hline Funding & Mainly public-funded & $\begin{array}{l}\text { Several sources of } \\
\text { funding }\end{array}$ \\
\hline Type of innovation & Public innovation & Social innovation \\
\hline Main beneficiary & Government is the main beneficiary & $\begin{array}{l}\text { Several beneficiaries: } \\
\text { universities, public or- } \\
\text { ganizations, private } \\
\text { companies, citizens } \\
\text { (quadruple helix } \\
\text { model) }\end{array}$ \\
\hline Methods & $\begin{array}{l}\text { Experimentation, co-creation and open inno- } \\
\text { vation methodologies }\end{array}$ & $\begin{array}{l}\text { Experimentation, co- } \\
\text { creation and open in- } \\
\text { novation methodolo- } \\
\text { gies }\end{array}$ \\
\hline
\end{tabular}

Despite the identification of different open innovation intermediaries in the public sector, many research questions remain unanswered: what is the specific role of these intermediaries in public innovation processes? How do they implement open innovation methodologies? What is the contribution of different public open innovation intermediaries to innovation outcomes? And, what determines these outcomes in the context of organizational intermediaries? It is therefore a necessary and interesting task to understand and compare the dynamics and contribution to public innovation of both i-labs and living labs. 


\section{Concluding remarks}

The purpose of this paper is to better understand open innovation in the public sector and the role of intermediaries. Based on this, this paper provides the following contributions:

- It collects and organizes the existing research about open innovation and open innovation intermediaries in the private and public sectors.

- It highlights the importance of open innovation intermediaries.

- It proposes a concept of open innovation intermediaries for the public sector.

- It identifies the characteristics of open innovation intermediaries.

- It considers the characteristics and challenges of the public sector context in terms of innovation.

After this review of previous studies, this paper provides a definition and some ideas for future research regarding open innovation in the public sector. Many interesting activities are happening in living labs and innovation labs that could improve our understanding of the role of intermediaries. We recognize that much is still needed in terms of empirical research about this topic. However, our aim with this paper is to start a discussion about this broad theme and call the attention of other researchers interested in open government innovation from multiple disciplines.

As mentioned before, open innovation intermediaries are currently working with governments around the world in diverse projects and through different methodologies and activities. More research is needed to understand this emerging phenomenon that links public and private sector organizations around innovation to generate value for citizens. In addition, open government innovation needs to be studied using different theoretical lenses and disciplinary perspectives. This will help to create an integrated view that helps government and citizens to face, and potentially solve, complex public problems.

\section{References}

1. Almirall, E. \& Wareham, J. Living labs: arbiters of mid- and ground-level innovation. Technology Analysis and Strategic Management 23(1), 87-102 (2011).

2. Almirall E. \& Wareham J. Living labs and open innovation: roles and applicability. The Electronic Journal for Virtual Organizations and Networks 10 (2008).

3. Amico-Roxas, S., Piroli, G. \& Sorrentino, M. "Efficiency and evaluation analysis of a network of technology transfer brokers". Technology Analysis and Strategic Management 23(1), 7-24 (2011).

4. Arnkil, R., Järvensivu, A., Koski, P. \& Piirainen, T. Exploring quadruple helix. Outlining user-oriented innovation models. University of Tampere - Institute for Social Research Work Research Centre, Tampere (2010).

5. Baccarne, B., Mechant, P. \& Schuurman, D. Empowered cities? An analysis of the structure and generated value of the smart city Ghent. In: R. P. Dameri \& C. Rosenthal-Sabroux (eds.). Smart city. How to create public and economic value with high technology in urban space, pp. 157-182. Springer, New York (2014). 
6. Bakici, T., Almirall, E. \& Wareham, J. The role of public open innovation intermediaries in local government and the public sector. Technology Analysis \& Strategic Management 25(3), 311-327 (2013).

7. Bason, C. Powering European public sector innovation: Towards a new architecture. Publications Office of the European Union, Luxembourg (2013).

8. Bekers, V., Tummers, L. \& Voornerg, W. From public innovation to social innovation in the public sector: A literature review of relevant drivers and barriers. Paper presented at the 2013 EGPA Conference. Edinburgh, September, 11-13, 2013.

9. Bekkers, V.J.J.M., Edelenbos, J. \& Steijn, B. Linking innovation to the public sector: contexts, concepts and challenges. In: VJJM Bekkers, J. Edelenbos \& B. Steijn (eds.). Innovation in the public sector. Linking capacity and leadership (Governance and Public Management, 6), pp. 3-34. Plagrave McMillan, Houndsmills (2011).

10. Bommert, B. Collaborative innovation in the public sector. International Public Management Review, 11(1), 15-33 (2010).

11. Chan, C. M. L. From open data to open innovation strategies: Creating e-services using open government data. In: Proceedings of the 46th Hawaii International Conference on System Sciences, pp. 1890-1899. IEEE, Los Alamitos, CA (2013).

12. Chesbrough, H. Open innovation: The new imperative from creating and profiting from technology. Harvard Business School Press, Boston (2006).

13. Chesbrough, H. The era of open innovation. MIT Sloan Management Review 44(3), 35-41 (2003).

14. Chesbrough, H.W. \& Bogers, M. "Explicating open innovation: Clarifying an emerging paradigm for understanding innovation”. In: Chesbrough, H., Vanhaverbeke, W. \& West, J. (eds.). New frontiers in open innovation, pp.3-28. Oxford University Press, Oxford (2014).

15. Christiansen, J. \& Bason, C. Profile of the public sector lab. Økonomistyring \& Informatik 26(4), 323-48 (2011).

16. Cleland, B., Mulvenna, M., Galbraith, B., Wallace, J. \& Martin, S. Innovation of e-participation strategies using living labs as intermediaries. Electronic Journal of e-Government 10(2), 120-132 (2010).

17. Daglio, M., Gerson, D. \& Kitchen, H. Building organisational capacity for public sector innovation. Paper presented at the OECD Conference "Innovating the Public Sector: From Ideas to Impact”. Paris, November 12-13, 2014.

18. De Vries, H., Bekkers, V. \& Tummers, L. Innovation in the public sector: A systematic review and future research agenda. Public Administration 94(1), 146-166 (2016).

19. Dias C. \& Escoval, A. The open nature of innovation in the hospital sector: the role of external collaboration networks. Health Policy and Technology 1(4), 181-186 (2012).

20. Feller, J., Finnegan, P., \& Nilsson, O. Open innovation and public administration: transformational typologies and business model impacts. European Journal of Information Systems 20, 358-374 (2011).

21. Füzi, A. Quadruple helix and its types as user-driven innovation models. Paper presented at the Triple Helix International Conference 2013. London, July 7-10, 2013.

22. Hennala, L., Parjanen, S. \& Uotila, T. Challenges of multi-actor involvement in the public sector front-end innovation processes: Constructing an open innovation model for developing well-being services. European Journal of Innovation Management 14(3), 364-387 (2011).

23. Hilgers, D. \& Ihl, C. Applying the concept of open innovation to the public sector. The International Journal of Public Participation 4(1), 67-88 (2010).

24. Hossain, M. Performance and potential of open innovation intermediaries. Procedia - Social and Behavioral Sciences 58, 754-764 (2012). 
25. Howells, J. Intermediation and role of intermediaries in innovation. Research Policy 35, 715728 (2006).

26. Kattel, R. \& Karo, E. "Start-up governments, or can bureaucracies innovate?". Blog of the Institute for New Economic Thinking, https://www.ineteconomics.org/perspectives/blog/start-up-governments-or-can-bureaucracies-innovate, last accessed 2017/05/17.

27. Lakomaa, E. \& Kalberg, J. Open data as a foundation for innovation: The enabling effect of free public sector information for entrepreneurs. IEEE Access, 1, 558-562 (2013).

28. Lee, M., Almirall, E. \& Wareham, J. Open data and civic apps: First-generation failures, second-generation improvements. Communications of the ACM, 59(1), 82-89 (2016).

29. Lee, S. M., Hwang, T. \& Choi, D. Open innovation in the public sector of leading countries". Management Decision 50(1), 147-162 (2012).

30. López-Vega, H. Open innovation. Organizational practices and policy implications. ESADE Business \& Law School, Barcelona (2012). Unpublished doctoral thesis.

31. Louis, C., Mergel, I., Bretschneider, S. \& Smith, J. Crowdsourcing policy innovations using Challenge.gov. Paper presented at the Public Management Research Conference. Madison, WI, June 20-22, 2013.

32. Mergel, I. Open innovation in the public sector. Paper presented at the 2015 International Summer School. Snekkersten, June 30, 2015a.

33. Mergel, I. Opening government. Designing open innovation processes to collaborate with external problem solvers. Social Science Computer Review 33(5), 599-612 (2015b).

34. Mergel, I. Implementing open innovation in the public sector: The case of Challenge.gov. Public Administration Review 73(6), 882-890 (2013).

35. Mergel, I. \& Desouza, K. Implementing open innovation in the public sector: the case of Challenge.gov. Public Administration Review, 73(6), 882-890 (2013).

36. Nesti, G. Urban living labs as a new form of co-production. Insights from the European experience. Paper presented at ICPP - International Conference on Public Policy II. Milan, July 1-4 (2015).

37. Osborne, S. \& Strokosch, K. It takes two to tango? Understanding the co-production of public services by integrating the services management and public administration perspectives. British Journal of Management 24(S1), S31-S47 (2013).

38. Schaffers, H. \& Turkama, P. Living labs for cross-border systemic innovation". Technology Innovation Management Review, September issue, 25-30 (2012).

39. Serra, A. Tres problemas sobre los laboratorios ciudadanos. Una mirada desde Europa. Revista Iberoamericana de Ciencia, Tecnología y Sociedad 8(23), 283-298 (2013).

40. Sørensen, E. \& Torfing. J. Collaborative innovation in the public sector: An analytical framework. Working paper no. 1/2010. Working Paper Series: Studies in Collaborative Innovation (2010).

41. Tonurist, P., Kattel, R., \& Lember, V. Discovering innovation labs in the public sector. Working paper no. 61. Working Papers in Technology Governance and Economic Dynamics 82015).

42. Vicini, S., Bellini, S. \& Sanna, A. The city of the future living lab". International Journal of Automation and Smart Technology 2(3), 201-208 (2012).

43. Von Hippel, E. Democratizing innovation. The MIT Press, Cambridge, MA (2005).

44. Winch, G. \& Courtney, R. The organization of innovation brokers: An international review". Technology Analysis and Strategic Management 19(6), 747-763 (2007).

45. Zuiderwijk, A., Helbig, N., Gil-Garcia, R. \& Janssen, M. Special issue on innovation through open data - A review of the state-of-the-art and an emerging research agenda: Guest editors' introduction. Journal of Theoretical and Applied Electronic Commerce Research 9(2), i-xiii (2014). 